\title{
Towards a Standing Committee Pursuant to Article 10 of the EU Tax Dispute Resolution Directive: A Proposal for Implementation
}

\author{
Sophia Piotrowski", Roland Ismer", Philip Baker", Jérôme Monsenego*, Katerina Perrou*, Raffaele Petruzzi", \\ Ekkehart Reimer", Fernando Serrano Antón", Lukasz Stankiewicz*, Edoardo Traversa* \& Jasna Voje*
}

The European Union Tax Dispute Resolution Directive 2017/1852 requires Member States to introduce mandatory arbitration for tax treaty disputes. In addition to the standard arbitration procedure laid down in the directive, Member States may also provide for dispute resolution by a Standing Committee. This contribution presents proposals for the implementation of such a Standing Committee.

\section{INTRODUCTION}

The OECD's BEPS actions have stipulated wide-ranging modifications to domestic tax laws and to tax treaties with the objective of closing perceived loopholes, which could give rise to excessive tax planning opportunities, and fighting aggressive tax planning. Such unilateral and bilateral measures will very likely increase the risk of double taxation or a taxation not in accordance with Double Taxation Conventions. The number of tax treaty disputes can also be expected to rise, be it through tougher tax audits, or more generally, due to a divergent understanding of facts, a different reading of the law or the significant increase in domestic treaty-overriding legislation. The fundamental changes envisaged as part of the work on the tax challenges of digitalization could further increase the number of disputes, given the complexity and the novelty of the alternatives considered. ${ }^{1}$ As a small consolation, the original mandate for BEPS had called for a commitment to mandatory binding arbitration. The commitment to arbitration can be seen as being part of the wider picture of a growing reliance on procedures rather than substantive rules. Where agreement on sufficiently precise substantive rules is hard to achieve or where precise substantive rules are thought to be particularly prone to give rise to tax avoidance, the OECD Model Tax Convention increasingly proposes procedural solutions. $^{2}$

The final report on Action 14 thus limited itself to more general proposals for strengthening dispute resolution mechanisms. ${ }^{3}$ Mandatory arbitration was then included in the Multilateral Convention to Implement Tax Treaty Related Measures to Prevent Base Erosion and Profit Shifting (MLI), albeit not as a minimum standard. The MLI's impact has also fallen short of expectations: Country Positions on MAP show a limited willingness by states to adopt arbitration. Few countries have so far signed up for Part VI and even those that have, have often notified comprehensive reservations. ${ }^{4}$

\section{Notes}

Sophia Piotrowski (sophia.piotrowski@fau.de) is a research associate on taxation at the Friedrich-Alexander-University Erlangen-Nuremberg (FAU). Roland Ismer (roland.ismer@fau.de) holds the Chair for Tax Law and Public Law at FAU. Philip Baker is a QC with Field Court Tax Chambers and a Visiting Professor at Oxford University. Jérôme Monsenego is a Professor of International Tax Law at Stockholm University. Raffaele Petruzzi is the Managing Director of the WU Transfer Pricing Center at the Institute for Austrian and International Tax Law at WU (Vienna University of Economics and Business) and an international tax advisor specializing in international corporate taxation and transfer pricing at L\&P Global (Vienna) and at Ludovici Piccone \& Partners (Milan). Katerina Perrou is a Researcher at IBFD, Amsterdam and Assistant Lecturer at the University of Athens Law School. Ekkehart Reimer holds the Chair for Public Law, European and International Tax Law at Heidelberg University; Fernando Serrano Antón holds the Chair for Financial and Tax Law as well as the TaxGov Jean Monnet Chair at the University Complutense of Madrid. Lukasz Stankiewicz is a Professor of Law at the Universite de Limoges. Edoardo Traversa is a Professor of Tax Law and the Head of the School of European studies at UCLouvain. Jasna Voje is an MSc in Taxation candidate at University of Oxford and a Contract agent at DG TAXUD, European Commission. This proposal is the outcome of a workshop by the Friedrich-Alexander-University Erlangen-Nuremberg (FAU) and Heidelberg University held on December $20 / 212018$ in Nuremberg. The opinions expressed in this article do not bind neither reflect the views of any organization the author is affiliated to. Financial Support by the registered charity Nürnberger Steuergespräche e.V. is gratefully acknowledged.

OECD, Public Consultation Document - Addressing the Tax Challenges of the Digitalisation of the Economy, 13 Feb. - 1 Mar. 2019, OECD/G20 Base Erosion and Profit Shifting Project (OECD Publishing 2019).

See e.g. Art. 4(3) OECD Model Tax Convention (2017)

OECD, Making Dispute Resolution Mechanisms More Effective: Action 14-2015 Final Report, OECD/G20 Base Erosion and Profit Shifting Project (OECD Publishing 5 Oct. 2015).

For an overview of country positions on the MLI see OECD, Signatories and Parties to the Multilateral Comvention to Implement Tax Treaty Related Measures to prevent Base Erosion and Profit Shifting, http://www.oecd.org/tax/treaties/beps-mli-signatories-and-parties.pdf (accessed 19 Feb. 2019). Most of the countries opting in for arbitration have opted for the default option of final offer arbitration or 'baseball arbitration' as provided for in Art. 23(1) of the MLI. MAP arbitration provisions are included in Part VI of the MLI. 
By contrast, the European Union (EU) has arguably changed the tax landscape for the better, when it adopted the new Dispute Resolution Directive (DRD) 2017/1852 in October 2017. ${ }^{5}$ It thereby introduced an obligatory instrument for more efficient dispute resolution. This move aims at fostering the internal market. ${ }^{6}$ Member States are obliged to implement the DRD by 30 June 2019. Its scope goes beyond the EU Arbitration Convention, a convention under public international law, which allowed and still allows for the resolution of transfer pricing disputes. ${ }^{7}$ The DRD in principle applies to all tax treaty disputes. ${ }^{8}$

Among the options offered by the DRD, the most innovative avenue seems to be the introduction of a Standing Committee: The directive provides for a standard dispute resolution procedure in its Articles 6ff. DRD. Where the competent authorities do not reach a comprehensive agreement, the dispute is solved by an ad hoc advisory commission. Under Article 10, Member States may also provide for dispute resolution by a Standing Committee. Article 10(1)(2) DRD expressly states that the Alternative Dispute Resolution Commission (hereinafter ADRC) may take the form of a Standing Committee, which can decide the case following the independent opinion approach or apply alternative methods of dispute resolution, such as baseball arbitration, Article 10(2)(2) DRD. Beyond that, however, the DRD is largely silent on the Standing Committee. All this means that Member States are presented a greenfield site available for developing a common mechanism of tax treaty arbitration.

At the same time, there are two significant risks: First, there is a risk of confusion. The ADRC, of which the Standing Committee is a sub-case, is not about non- binding alternative dispute resolution. Rather, it offers a different path to reaching a binding resolution. This is in contrast to the possibility of relying on alternative dispute resolution mechanisms in the MAP stage: According to Recital (6), Member States should be encouraged to use non-binding alternative dispute resolution forms, such as mediation and conciliation, during the final stages of the MAP. Second, and more importantly, there is a substantive risk that the independence of the arbitrators is not guaranteed to a sufficient extent: Article 10 DRD does not contain a reference to the list of independent persons under Article 9 DRD, according to which such persons must be 'competent and independent, and [who] can act with impartiality and integrity'. Instead, it only contains a reference to Article 8(4) and (5), which allows the competent authorities to reject arbitrators based on a lack of independence with respect to a specific case. In the worst case, Article 10 DRD may thus be relied upon to implement a dispute resolution procedure that guarantees neither the independence of arbitrators nor - for lack of pertinent guarantees - sufficient taxpayer protection. To eliminate this substantive risk, we contend that a proposal for a Standing Committee should be ambitious and strive for meaningful improvements of tax treaty dispute resolution through a truly independent Standing Committee.

Indeed, a rich scholarly literature deals with the shortcomings of existing dispute resolution mechanisms and makes proposals for improvements. ${ }^{10}$ The DRD has also given rise to a significant number of academic contributions, which have thus far mainly focused on the standard procedure for dispute resolution provided for by the directive and the relationship of the directive to other existing mechanisms. ${ }^{11}$ There are very few contributions, which

\section{Notes}

Council Directive (EU) 2017/1852 of 10 Oct. 2017 on tax dispute resolution mechanisms in the European Union, OJ L $265 / 1$ (14 Oct. 2017).

Recital (1) DRD. See European Commission, Commission Staff Working Document Impact Assessment, Accompanying the Proposal for a Council Directive on Double Taxation Dispute Resolution Mechanisms in the European Union, SWD(2016) 343 final (25 Oct. 2016), https://ec.europa.eu/taxation_customs/sites/taxation/files/swd_2016_343_en.pdf (accessed 19 Feb. 2019).

Convention on the elimination of double taxation in connection with the adjustment of profits of associated enterprises 90/463/EEC, OJ L 225/10 (20 Aug. 1990).

8 Art. 1 DRD

9 Critical of this definition: S. Govind \& L. Turcan, The Changing Contours of Dispute Resolution in the International Tax World: Comparing the OECD Multilateral Instrument and the Proposed EU Arbitration Directive, 71(3/4) Bull. Int'l Tax'n (2017), Ch. 3.4.

10 See e.g. Z. D. Altman, Dispute Resolution Under Tax Treaties, Doctoral Series Vol. 11 (IBFD 2006); G. Lindencrona \& N. Mattson, Arbitration in Taxation (Kluwer 1981); K. Perrou, Taxpayer Participation in Tax Treaty Dispute Resolution. Doctoral Series Vol. 28 (IBFD 2014); F. Serrano Antón, Resolución de conflictos en el Derecho internacional tributario: procedimiento amistoso y arbitraje (Civitas 2011); N. Strotkemper, Das Spannungsverbältnis zwischen Schiedsverfabren in Steuersachen und einem Internationalen Steuergerichtshof (Nomos Verlag 2014).

11 L. Cerioni, The Commission's Proposal for a Directive on Double Taxation Dispute Resolution Mechanisms: Overcoming the Final Hurdle of Juridical Double Taxation Within the European Union?, 57(5) Eur. Tax'n (2017); CFE Fiscal Committee, Opinion Statement FC 4/2017 on the Proposed Directive on Double Taxation Dispute Resolution Mechanisms in the European Union, 57(8) Eur. Tax'n (2017); F. Debelva \& J. Luts, The European Commission's Proposal for Double Taxation Dispute Resolution: Turning the Tide?, 71(5) Bull. Int'l Tax'n (2017); D. De Carolis, The EU Dispute Resolution Directive (2017/1852) and Fair Trial Protection Under Art. 47 of the EU Charter of Fundamental Rights, 58(11) Eur. Tax'n 495 (2018); S. Govind, The New Face of International Tax Dispute Resolution: Comparing the OECD Multilateral Instrument with the EU Dispute Resolution Directive 27(6) EC Tax Rev. 309 (2018); Govind \& Turcan, supra n. 9; G. Groen, Why the Revised EU Arbitration Directive Is a Big Step in the Right Direction, 87 Tax Notes Int'l 475 (2017); S. Grotherr, Verbesserte Wirksamkeit von Streitbeilegungsverfabren zur Lösung von Doppelbesteuerungskonflikten, Recht der internationalen Wirtschaft 331 (2017); S. Grotherr, Verbesserungen zur Streitbeilegung bei Doppelbesteuerungskonflikten, Betriebs-Berater I (2017); G. Luchena Mozo, A Collaborative Relationship in the Resolution of International Tax Disputes and Alternative Measures for Dispute Resolution in a Post-BEPS-Era, 58(1) European Taxation 22 (2018) K. Hafner \& M. Stiastny, Die EU-Streitbeilegungsrichtlinie - eine Vorstellung, Steuer und Wirtschaft International 12 (2018); D. Oosterhoff, New Rules to Resolve Tax Disputes, 25(1) Int'l Transfer Pricing J. 11 (2018); S. Rasch, EURichtlinienvorschlag über Verfabren zur Beilegung von Doppelbesteuerungsstreitigkeiten in der EU - Überblick und erste Anmerkungen, 6(2) Internationale Steuer-Rundschau 43 (2017); N. Strotkemper, Reformiertes Streitbeilegungsverfahren für Doppelbesteuerungskonflikte in der EU, Internationales Steuer- und Wirtschaftsrecht 55 (2018); J. Voje, EU Tax Dispute Resolution Directive (2017/1852): Paving the Path Toward a European Tax Court?, 58(7) Eur. Tax'n 309 (2018); T. Wiertsema, Council Directive on Double Taxation Dispute Resolution Mechanisms: 'Resolving Companies' Areas of Concern?', 19(5) Derivatives \& Fin. Instruments (2017); G. Zeyen, When Taxation Meets Arbitration: Recent Initiatives to Introduce and Promote Arbitration in International and European Taxation, 45(11) Intertax 722 (2017); T. Zinowsky \& J. Schönfeld, Verfabren zur Beilegung von Streitigkeiten in Doppelbesteuerungssituationen - Überblick. über die neue EU-Ricbtlinie, 7(1) Internationale Steuer-Rundschau (2018). 
explicitly deal with the Standing Committee under Article $10 .^{12}$

What is new, however, is the Standing Committee under Article $10 \mathrm{DRD}$, on which the following contribution will concentrate. We believe that this provision offers a unique chance for a meaningful improvement of dispute resolution within the internal market, and, potentially, even for developing a role model for a more permanent form of tax treaty arbitration. If properly designed, tax treaty dispute resolution would benefit from the experience and specialization of arbitrators, an institutional accumulation of pertinent know-how and resources, guaranteed availability of arbitrators, transparency, legal certainty for all stakeholders, an increased quality and uniformity of decisions as well as a higher standard of taxpayer protection. The Standing Committee also offers the prospect of major advances regarding the understanding and further development of substantive tax treaty law: While its case law would not serve as a formal precedent - this is even explicitly ruled out by Article 15(4) DRD - it may nevertheless provide a common point of departure for future tax treaty disputes, thanks to the publication of the decisions (or abstracts thereof). ${ }^{13}$ As such, it may even contribute to evolutionary lawmaking. ${ }^{14}$

Ideally, our proposal would be implemented for all tax treaty disputes between Member States. However, as long as there is a critical mass of Member States wishing to introduce a Standing Committee, the impact of such instrument may be substantial. Our proposal therefore has to tackle the essential challenges, which any proposal for tax treaty dispute resolution faces: finding a fair, effective, speedy and transparent solution based on law and in accordance with taxpayer rights at reasonable cost to all stakeholders, i.e. Member States, taxpayers, European Union institutions, as well as arguably society at large. At the same time, Member States' tax sovereignty must be sufficiently safeguarded and acceptability to the public ensured for such proposal to achieve a broad consensus.

Our contribution starts with an overview of the legal framework of the DRD (II.) It then points out the implications following from the prerequisite that the proposal must be compatible with EU law, Member States' constitutional law, and the ECHR. It also identifies as objectives of such proposal (1) a speedy, inexpensive and comprehensive resolution of disputes; (2) legal certainty and guaranteeing the rule of law; (3) taxpayer protection; and (4) transparency and acceptability; as well as (5) possibly the contribution to the future development of international tax law (III.). Subsequently, the article makes concrete proposals for the implementation of a Standing Committee pursuant to the DRD (IV.). A short summary and outlook will conclude this contribution (V.).

\section{Legal fRAMEWORK OF THE DRD}

\section{I The Standard Dispute Resolution Procedure Under the DRD}

When it comes to the standard dispute resolution mechanism under the directive, three stages can be distinguished, namely (2.1.1) the complaint stage, (2.1.2) the MAP stage and (2.1.3) the arbitration stage.

\section{I.I Complaint Stage}

The complaint stage is launched where an affected person complains to the competent authorities of all Member States concerned. ${ }^{15}$ Depending on the course of action of the competent authorities, the picture may then become quite complex, if not confusing. All in all, four cases may be distinguished:

(1) First, the competent authorities may unilaterally address the complaint and thus resolve the question in dispute.

(2) Second, the competent authorities may accept the complaint. Where all competent authorities of the Member States concerned accept the complaint, the MAP stage is initiated.

(3) Third, where at least one competent authority has accepted the complaint, but at least one competent authority has rejected $i t,{ }^{16}$ the affected person in turn has two options: she may either seek to overturn the rejection in front of the respective national court. Alternatively, an advisory commission pursuant to Article 6(1)(a) and (2) DRD may be set up, which then decides on the acceptance of the complaint. This advisory commission may be dubbed 'Procedural Advisory Commission' (PAC). Where the complaint is accepted by the PAC, the MAP stage

\section{Notes}

\footnotetext{
12 See however Govind, supra n. 11, at 318ff.

13 Art. 18 DRD.

14 R. Ismer, MAP and Arbitration as Remedies for Double Burdens: Evolutionary Law-Making through Procedural Rather Than Substantive Rules, in Double Taxation Within the European Union $211 \mathrm{ff}$ (A. Rust (ed.), Kluwer 2011).

15 There are however simplifications for individuals and smaller undertakings pursuant to Art. $17 \mathrm{DRD}$. The affected persons covered by this provision only need to complain to one of the competent authorities involved in the dispute.

16 The competent authority may only reject the complaint based on the grounds of Art. 5(1) DRD. This means in particular that the complaint may be rejected for the mere reason that the taxpayer pursues domestic remedies at the same time, in order to safeguard the time limits imposed by national law.
} 
is initiated, provided that at least one competent authority so requests. Where none of the competent authorities requests the initiation of the MAP within sixty days, the dispute automatically moves to the arbitration stage.

(4) Fourth, where none of the competent authorities have accepted the complaint, the person concerned has to adhere to Article 5(3) DRD before being able to resort to the procedure pursuant to Article 6(1)(a).

\subsubsection{MAP Stage}

Where the competent authorities of the Member States concerned accept a complaint, they shall endeavour to resolve the question in dispute by mutual agreement within two years, Article 4(1) DRD. This period may be extended by up to one year. The MAP stage either ends with (Article 4(2) DRD) or without (Article 4(3) DRD) an agreement of the competent authorities.

\subsubsection{Arbitration Stage}

Where no agreement is reached in the MAP stage, the affected person may request that an advisory commission be set up, Article 6(1)(b), (3) DRD. This advisory commission, which we propose to dub 'Substantive Law Advisory Commission' (SLAC), is in principle identical to the PAC, where the latter was previously set up in the complaint stage. The SLAC delivers its opinion based on the independent opinion approach within six months after the date on which it was set up. ${ }^{17}$ Articles $7 \mathrm{ff}$. DRD offer guidance as to the composition and the appointment of the PAC and the SLAC. Articles 11ff. DRD then contain procedural provisions.

The competent authorities then have another opportunity to resolve the dispute, Article 15(1) DRD. If they fail to do so within a time span of six months, the opinion of the SLAC becomes binding for the competent authorities (final decision), Article 15(2) DRD. The decision then has to be implemented provided the affected person accepts it and waives her right to domestic remedies. This insurmountable obligation to implement the final decision under Article 15 DRD stands in contrast to traditional tax treaty arbitration, where depending on the national constitutional law of the contracting states there might be no absolute obligation to implement arbitral awards (tax treaty overrides). The final decisions are published either in their entirety or, where the affected person does not consent, in the form of an abstract only, Article 18 DRD.
Finally, Article 16 DRD contains rules on the relationship to domestic remedies and other dispute resolution mechanisms. According to Article 16 (1), (2) and (3) DRD the procedure under the Directive and national remedies are in principle independent. However, a Member State, which does not allow deviations from national court decisions may terminate both the mutual agreement procedure and the arbitration stage to the extent that no agreement has been reached and no arbitral award has been rendered, Article 16(4) DRD. The dispute resolution under the DRD takes precedence over other forms of dispute resolution, once a corresponding complaint has been received by either competent authority, Article 16(5) DRD. Article 16(6), and on a case-by-case basis Article 16(7) $\mathrm{DRD}$, contain derogations. Where those grounds are concerned, the competent authorities arguably nevertheless have to accept the complaint and enter into a MAP. ${ }^{18}$

The rules on the arbitration stage - by law - thus only require finding a (any) solution to the dispute. Just as traditional MAP was about reaching any agreement between the contracting states that was acceptable to the taxpayer involved, the decision resulting from the arbitration stage can be any decision acceptable to the taxpayer - at least from a public international law point of view. This is also demonstrated by the possibility for the Member States to agree to a different solution under Article 15(2) DRD. Constraints may, however, arise from domestic law, as the competent authorities may be bound by law, as well as State aid law. The publication requirement under Article 18(2) DRD provides no decisive counter-argument as it does not concern the opinion, but the final decision. However, from a policy perspective, the procedure should be directed at arriving not just at any, but rather at the 'right' solution.

\subsection{Legal Framework for the Establishment of a Standing Committee}

Article 10 allows for an alternative to the SLAC (Article 6) in the arbitration stage of the procedure. Any proposal for such alternative has to keep within the boundaries of the DRD. Otherwise, a new legislative basis would be required for establishing a more comprehensive proposal for a Standing Committee. Articles 1 to 5 apply regardless of which procedure is chosen for the arbitration stage. It is only where the mutual agreement procedure fails (or where the Competent Authorities do not initiate a MAP after a decision by the PAC) that a Standing Committee may be set up as an alternative to the SLAC pursuant to Article 6(1)(b) DRD. ${ }^{19}$ Any design options regarding the Standing Committee are therefore limited to the

\section{Notes}

17 This period may be extended by three months.

18 Whether these provisions also refer to the PAC does not emerge clearly from the directive.

19 Art. 10 DRD explicitly only allows for the possibility of an alternative dispute resolution when it comes to the resolution of the question in dispute in accordance with Art. 10 DRD. The procedure pursuant to Art. 6(1)(a) DRD is therefore not covered. 
arbitration stage. Article 16f. DRD are similarly applicable regardless of the type of procedure chosen for the third step of the dispute resolution procedure. Articles 14 (Opinion of the SLAC or Alternative Dispute Resolution Commission), 15 (Final Decision) and 18 (Publicity) concern the opinion both of the SLAC and of the Alternative Dispute Resolution Commission as well as the time span after such opinion has been rendered. In these articles, the directive explicitly refers to both options of dispute resolution. This means that once a decision has been rendered, the procedure is again identical. In particular, the competent authorities have another six months to come to a final decision, before the opinion of the SLAC or the Alternative Dispute Resolution Commission becomes binding for them. The Commission has but a limited role in the procedure. Under Article 20 DRD, it may pass implementing regulations. However, these require a mandate within the DRD, which only exists with respect to standard Rules of Functioning and the publication of the final decision.

Beyond that, there is considerable leeway for institution design when it comes to the composition of the arbitration board and the applicable procedures: Article 10 does not give comprehensive guidance on what a Standing Committee could (and should) look like. Instead, it only provides some basic features of such Alternative Dispute Resolution Commission, and in particular a Standing Committee. According to Article 10(2), the composition of an ADRC has to adhere to only Articles 8(4), (5) DRD, which contain independence and impartiality requirements. Moreover, Article 10(3) DRD requires that the competent authorities agree on Rules on Functioning pursuant to Article 11 DRD. Article 10(4) contains a default rule, according to which the provisions on cost and information, evidence and hearing (Articles 12 and 13) are applicable unless otherwise agreed in the Rules of Functioning.

\section{OBJECTIVES OF INTRODUCING A STANDING COMMITTEE}

\section{I Prerequisite: Ensure Compatibility with EU Law, Member States' Constitutional Law, and the European Convention on Human Rights}

As a prerequisite, the introduction of a Standing Committee needs to be compatible not only with the boundaries laid down in the DRD, ${ }^{20}$ but also with other

Figure 1 Dispute Resolution Under the DRD

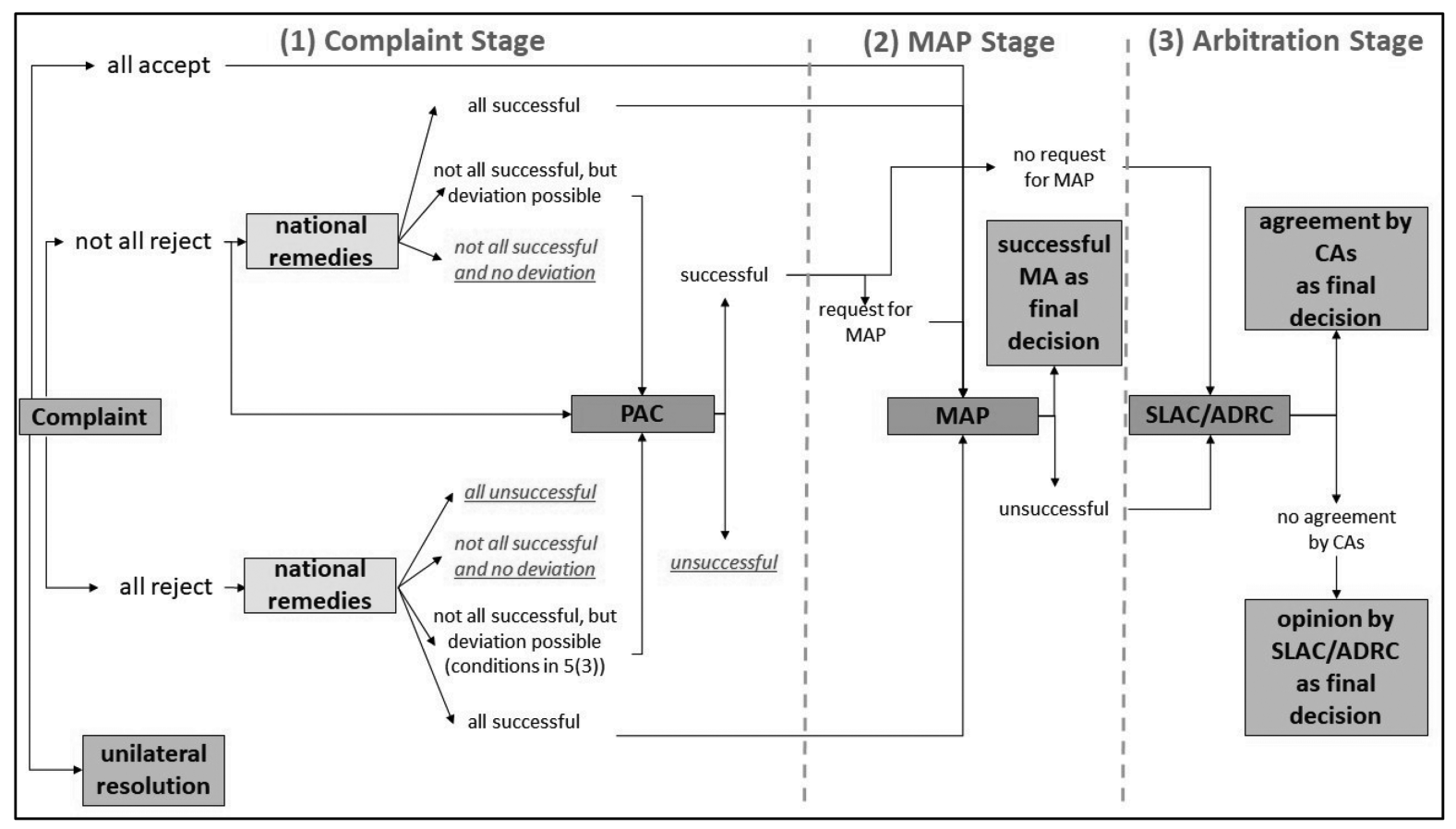

PAC - Procedural Advisory Commission, Article 6(1)(a) DRD

SLAC - Substantive Law Advisory Commission, Article 6(1)(b) DRD

ADRC - Alternative Dispute Resolution Commission, Article 10 DRD

\section{Notes}

20 See supra s. II.2. 
sources of EU law, Member States' constitutional law and the European Convention on Human Rights. We will focus on two highly problematic points here, namely the implications of the judgment of the CJEU in Achmea $B V^{21}$ and the applicability of Article 47 of the Charter of Fundamental Rights. ${ }^{22}$ It should be noted that similar questions arise for the SLAC under Article 6(1)(b) DRD.

In the Achmea $B V$ decision, ${ }^{23}$ the CJEU held that the arbitration panel established under the bilateral investment treaty between the Netherlands and the Slovak Republic had to apply European Union law to solve the dispute. Yet, while arguably being a court or tribunal, as it provided for a binding resolution of the dispute, it was not a court or tribunal of a Member State. The competence of the arbitration panel was moreover created by an agreement which was concluded by Member States rather than the EU. The arbitration panel therefore could not make a reference for a preliminary ruling to the CJEU under Article 267 TFEU. Member States had thus agreed on submitting disputes to a body which is not part of the judicial system of the EU which could render binding decisions on the interpretation of European Union law. All this means that the arbitration clause in a bilateral investment treaty between two Member States violated Articles 267 and 344 TFEU. Whether the reasoning can be transferred to the Standing Committee - or, for that matter, to the SLAC - is presently unclear: EU Member States are obliged by European Union Law to establish the SLAC or, as an alternative, the ADRC, which may take the form of a Standing Committee. Even if the Standing Committee is adopted by only some Member States, this cannot be seen as a breach of the loyalty obligation under Article 4(3) TEU, as such possibility is expressly allowed under the DRD. This appears to be supported by the fact that Advocate General Bot recently considered the arbitration provided for in the CETA agreement compatible with EU law, as it was an agreement of the EU itself with a third country instead of an agreement between Member States. ${ }^{24}$ This in turn may mean that while arbitration clauses in tax treaties between Member States may well fall foul of EU law, the Achmea BV judgment should not have wider implications for the DRD. Where arbitral panels meet the requirements of a court or tribunal, they are to be considered as a court or tribunal of a Member State. Moreover, the Standing Committee, just as the SLAC, would in certain cases have to apply EU law and guarantee the correct application thereof. EU law, such as the fundamental freedoms and the state aid provisions, can be of relevance in tax treaty disputes between Member States. Moreover, the DRD itself is EU law so that any dispute resolution procedure under the directive involves the application of EU law. ${ }^{25}$

By contrast, Article 47 of the Charter guarantees the right to an effective remedy and to a fair trial. Were the Standing Committee a tribunal pursuant to Article 47, it would have to comply with the requirements laid down in this provision.

Both the implications of the judgment of the CJEU in Achmea $B V$ and the applicability of Article 47 of the Charter of Fundamental Rights therefore depend on whether the Standing Committee is a court or tribunal in the sense of Article 47 of the Charter of Fundamental Rights and Article 267 TFEU. We believe that the answer should be identical for both provisions.

In its long-standing case law, the CJEU considers the question of whether a body is a court or tribunal to be solely governed by Union law. According to this case-law, several factors have to be taken into account, such as whether the body is established by law, whether it is permanent, whether its jurisdiction is compulsory, whether its procedure is inter partes, whether it applies rules of law and whether it is independent'. ${ }^{26}$ Permanence requires the institutionalization of arbitration as a dispute settlement method. This is the case where the arbitration panel 'was established on a legislative basis, ... it [had] permanent compulsory jurisdiction and, in addition, ... national legislation define[d] and frame[d] the applicable procedural rules', even though it might vary in form, composition and rules of procedure, according to the choice of the parties, and even though it was dissolved after making its decision. ${ }^{27}$ More specifically, the Court of Justice has had to decide several times whether an administrative tribunal which is not part of Member States' judicial systems is a court or tribunal in the sense of Article 267 TFEU. $^{28}$ While the case law on this matter has been described as 'blurred' and 'internally

\section{Notes}

21 DE: CJEU 6 Mar. 2018, Case C-284/16, Slovak Republic v. Achmea BV, ECLI:EU:C:2018:158. See also BE: Opinion Advocate General Yves Bot 29 Jan. 2019, Avis 1/17, Accord ECG UE-Canada, ECLI:EU:C:2019:72.

22 On this De Carolis, supra n. 11.

23 Slovak Republic v. Achmea BV (C-284/16), supra n. 21

24 Opinion by Advocate General Yves Bot, (Avis 1/17), supra n. 21.

25 M. Villar Ezcurra, Implicaciones del caso «Achmea» en asuntos fiscales: límites al arbitraje, jurisdicción exclusiva del TJUE y Comvenios de Doble Imposición internacional, 1 Quincena Fiscal 2, 147 (2019).

26 DE: CJEU 17 Sept. 1997, Case C-54/96, Dorsch Consult Ingenieurgesellschaft mbH, ECLI:EU:C:1997:413, para. 23 with reference to e.g. NL: CJEU 30 June 1966, Case C-61/ 65, Vaassen (neé Göbbels), ECLI:EU:C:1966:39, at 273; IT: CJEU 11 June 1987, Case C-14/86, Pretore di Salò v. Personsunkown, ECLI:EU:C:1987:275, para. 7; DK: CJEU 17 Oct. 1989, Case C-109/88, Danfoss, ECLI:EU:C:1989:383, paras 7f.

27 Cf. Opinion AG Wathelet 19 Sept. 2017, C-284/16, Slovak Republic v. Achmea BV, ECLI:EU:C:2017:699 para. 101 and 103 with extensive references to the Court's case law.

28 R. García Antón, 'Ceci n'est pas une Pipe': The Notion of Tax Court Under Article 267 of the TFEU, 55(11) Eur. Tax'n 515, 516 (2015), with reference to LU: CJEU 30 Mar. 1993, Case C-24/92, Corbiau, ECLI:EU:C:1993:118; ES: CJEU 21 Mar. 2000, Joined Cases C-110/98 to C-147/98, Gabalfrisa and Others ECLI:EU:C:2000:145; AT: CJEU 
contradictory', it appears as though the determination of whether an administrative body qualifies as a court or tribunal mainly hinges on the questions of the independence of the administrative body ${ }^{29}$ and compulsory jurisdiction - including whether the decision is binding on the parties. ${ }^{30}$ While De Carolis holds the view that the independence requirement is fulfilled due to the fact that there is a simultaneous presence of independent persons of standing and a chair which is to be chosen from amongst them, we consider that at least the majority of members needs to be independent. ${ }^{31}$ Moreover, one point that would speak against qualifying the Standing Committee as well as the SLAC as a court or tribunal is that their decisions are not necessarily binding. First, the competent authorities of the Member States involved may subsequently arrive at a divergent solution. Second, even where they do not achieve this, the decision only becomes binding when the taxpayer accepts it. Another aspect is that the arbitration stage is an extension of the MAP stage. At least historically, it is an administrative procedure, so that there seems to be some merit in not considering the arbitral panel a tribunal pursuant to Article 267 TFEU. Otherwise, even the MAP stage would be problematic from that angle. However, on the other hand, the possibility for a review of the decision is very limited under the directive. More importantly, from an effet utile perspective, it seems warranted that final decisions on the application and interpretation of EU law be subject to review by the CJEU.

How then can the compatibility with primary law be ensured? As to Article 47, the answer is fairly straightforward: The Standing Committee should comply with the requirements laid down in Article 47. Applying the standards imposed by that provision appears desirable from a policy point of view as the provision enshrines a high standard of taxpayer protection, which should be one of the main objectives of the implementation of a Standing Committee. With regard to the Achmea $B V$ decision, however, the consequences are less clear. ${ }^{32}$ As the Standing Committee is competent to interpret or apply EU law, a possibility to provide for legal review by the CJEU may have to be included. Conceptually there are thus two design options: To be on the safe side, one could turn it into a structure that fulfils the requirements of a court or tribunal. The Standing Committee would then (need to) have the competence to refer questions on the interpretation of EU law to the CJEU pursuant to Article $267 \mathrm{TFEU}^{33}$ and the arbitral tribunal would be bound by the judgment of the CJEU. The fact that the competent authorities are subsequently authorized to take a decision which diverges from the opinion of the Standing Committee does not lead to a different conclusion. As part of the executive branch, the competent authorities are also bound by the judgment of the CJEU. In such cases, the possibility of a subsequent divergent decision hence seems to be innocuous. Alternatively, one may design the Standing Committee in a way that it does not resemble a court. Then the opinion by the Standing Committee would have to be subject to review by a court or tribunal of a Member State when it comes to the interpretation of EU law. In turn, that court or tribunal could refer the matter to the CJEU.

Constitutional law may impose further requirements on the design of a Standing Committee procedure. The Greek constitution, for example, requires decisions to have reasoned justifications. ${ }^{34}$ These concerns are not eliminated based on the primacy of EU law for two reasons: First, the Standing Committee procedure is optional for Member States. Second, even if it were mandatory, an application of a reasoned justification approach would not be ruled out by the directive. Consequently, there would be room for Member States' constitutional law requirements to be fulfilled. Moreover, the concerns regarding the national balance of powers need to be heeded: When arbitration is seen as forming part of the executive branch of government; there may also be information rights of parliament that need to be guaranteed.

\subsection{Objective I: Ensure a Speedy, Inexpensive and Comprehensive Resolution of the Dispute}

Dispute resolution by an ADRC, and in particular a Standing Committee should ensure a speedy, inexpensive and comprehensive resolution of the dispute.

\section{Notes}

30 May 2002, Case C-516/99, Schmid, ECLI:EU:C:2000:145; SE: CJEU 12 Nov. 1998, Case C-134/97, Victoria Film, ECLI:EU:C:1998:535; LT: CJEU 21 Oct. 2010, Case C-385/09, Nidera Handelscompagnie, ECLI:EU:C:2001:627.

29 De Carolis, supra n. 11, at $502 \mathrm{f}$

30 García Antón, supra n. 28, at 517ff.

31 De Carolis, supra n. 11, at 503.

32 On this see e.g. De Carolis, supra n. 11, at $502 \mathrm{f}$.

33 For capacity reasons a probably rather theoretical possibility would be to designate the CJEU as the Standing Committee under Art. 273 TFEU. This has a role model in the Austrian-German tax treaty, see DE: CJEU 12 Sept. 2017, Case C-648/15, Austria v. Germany, ECLI:EU:C:2017:664.

34 If the standing committee qualifies as a 'court or tribunal' GR: Art. 93(3) Constitution provides that: 'Every court judgment must be specifically and thoroughly reasoned and must be pronounced in a public sitting'. Decisions of the tax administration are also subject to the same requirement, even though no explicit rule is found in the Constitution. The obligation to provide justification is emanating from the principle of legality of the tax, i.e. provided in GR: Art. 78(1) Constitution, which provides that 'No tax shall be levied without a statute enacted by Parliament, specifying the subject of taxation and the income, the type of property, the expenses and the transactions or categories thereof to which the tax pertains.' Accordingly, GR: Art. 64 Tax Procedures Code: 'The tax administration has the obligation to provide full, specific and adequate justification regarding the legal basis, the facts and the circumstances that lead to the tax assessment'. 
Costs should be minimized. This goes both for the cost of the institution as a whole and for the resolution of the single case. In this respect, the specialization of arbitrators is advantageous.

As to the comprehensive resolution of the case, it is necessary to identify what the objective of the DRD is. There is certainly the goal of avoiding double taxation or a taxation not in accordance with a DTC. However, these goals are not necessarily identical to the resolution of the dispute. It is not sufficient simply to get rid of double taxation by applying any solution regardless of whether this is in line with the law. While it is true that the taxpayer will often not care how the dispute gets resolved as long as the double taxation is eliminated, the further goal should be to develop a 'right' way of resolving the dispute. This is also a consequence of the legal source being interpreted, namely the applicable agreement or convention', Articles $3(3)(\mathrm{d})$ and 14(2). The arbitrators should thus seek for the correct application of the actual tax treaty, as possibly amended by the MLI; this should also include taking into consideration which interpretative sources may be relied upon in the case under review. Moreover, the question is whether the DRD also strives for an avoidance of double non-taxation or ensuring single taxation. Should the improper use of DTCs be avoided through the DRD? The answer to these questions determines whether certain cases should be kept out of the proposed streamlined procedure in front of the Standing Committee. Article 16(7) DRD contains some guidance in this respect. It offers competent authorities the option to deny taxpayers access to the SLAC where there is no double taxation. Yet they are not obliged to make use of this option. Consequently, there may nevertheless be cases, which do not feature double taxation, which make it to the third stage of the dispute resolution procedure.

Another aspect to this is that further disputes both regarding the implementation of the decision of the Standing Committee and future tax years should be avoided. Beyond that, ideally the resolution of a case would provide some sort of guidance to other taxpayers, who face a similar issue. However, in this respect, Article 15(4) DRD has to be kept in mind, which explicitly excludes precedential value. Yet at least some degree of consistency in decisions may emerge in the future given that decisions under the directive will be published pursuant to Article 18 DRD.

\subsection{Objective 2: Ensure Legal Certainty and Guarantee the Rule of Law}

Another important objective of the establishment of a Standing Committee should in our view be that legal certainty is ensured and that the rule of law is guaranteed. This is with regard to the quality of the decisions of a Standing Committee. Decisions taken by the Standing Committee should be correct, i.e. particularly based on a correct understanding of the underlying law. This may particularly be problematic where a DTC refers to the domestic law of one of the parties to the dispute.

Ensuring legal certainty and the guarantee of the rule of law throughout the entire procedure is particularly important based on the fact that there is an increasing reliance on procedural rather than substantive rules in international tax law - an example of which is the DRD. Particularly where there is leeway, it is necessary to avoid improper influences on the arbitrators deciding the case. The independence of arbitrators has to be ensured.

\subsection{Objective 3: Guarantee Taxpayer Protection}

Dispute resolution by a Standing Committee should ensure a high degree of taxpayer protection. ${ }^{35}$ Not only is this desirable from a tax policy point of view, we contend it is also mandated by Article 47 of the Charter of Fundamental Rights. Taxpayer protection in this context involves aspects, such as the preservation of confidential information, ensuring the right of the taxpayer to be heard and to intervene. Beyond this, one may wonder whether the taxpayer should be a party to the dispute. If this were not the case, there would be dangers to taxpayer protection as arbitration procedures are characterized by party autonomy. At the same time, the standing of the taxpayer may have implications for the position of the representatives of Member States. ${ }^{36}$ Finally, it is necessary to ensure both accessibility and factual equal treatment for small and medium taxpayers.

\subsection{Objective 4: Ensure Transparency and Acceptability}

The dispute resolution procedure by a Standing Committee should strive for a high degree of transparency. This concerns two aspects: First, the process of establishing a Standing Committee should be sufficiently transparent. This is particularly relevant where only some Member States decide to implement a Standing

\section{Notes}

35 On the importance of taxpayer protection see also P. Baker \& P. Pistone, BEPS Action 16: The Taxpayers' Right to an Effective Legal Remedy Under European Law in Cross-Border Situations, 25(5/6) EC Tax Rev. $335 \mathrm{ff}$ (2016).

36 See below Proposal $3 a$. 
Committee. Second, the transparency of the procedure in front of the Standing Committee itself has to be guaranteed. In this context, two contrasting issues may be brought forward: The taxpayer will generally be concerned with the preservation of confidential information and may therefore prefer a limited degree of publicity and transparency. With regard to the decision itself Article 18 DRD provides that the final decision or at least an abstract thereof has to be published. However, the taxpayer may not wish to see public hearings of the SLAC or even a live broadcast as is the case for some hearings of the ICSID as well as for domestic court procedures in countries, such as Canada or Australia. Conversely, transparency can also refer to decision making procedures. A high degree of the latter is in the interest of the taxpayer. Particularly where representatives of the competent authorities are part of the arbitral tribunal, there is a danger that cases are not solely decided on their merits and that other considerations play a role instead. The decisionmaking procedure and the appointment of the arbitral tribunal should therefore be sufficiently transparent. This also plays into the obligation to state reasons in decisions. ${ }^{37}$ On a more abstract level, transparency is a key aspect of the acceptability of a Standing Committee to all stakeholders.

Acceptability is important both with regard to the likelihood of adoption and to the existence of the Standing Committee once established. First, the Member States are the most relevant stakeholders as they will be the ones adopting a Standing Committee under Article 10 DRD. This means that it is particularly important that a proposal for a Standing Committee is drafted with Member States' tax sovereignty in mind. In particular, a balance has to be struck between a sufficient degree of taxpayer protection through the establishment of a courtlike structure on the one hand and the preservation of tax sovereignty on the other hand. Member States will thus likely seek to retain as much control over the procedure as possible. They will also seek to limit the role of the taxpayer. This is to say that while we should certainly strive for an ambitious and innovative proposal, the likelihood of adoption always has to be kept in mind and we have to conduct a reality check at all times. The Standing Committee should not be designed in a way that will put off Member States that would in principle be open to its introduction. We should rely on the experience gained under other international dispute resolution mechanisms, such as the EU Arbitration Convention, so as to specifically address the shortcomings therein. If the Standing Committee were not adopted by all the Member States, it would be pivotal to provide an option for other Member States to join at a later stage. It would thus be necessary to clearly flag the establishment of the Standing Committee as a trial phase. A proposal for a Standing Committee should also be kept as simple as possible, so as to increase the likelihood of adoption. Finally, the adoption of a Standing Committee may not lead to an undue prerogative for any particular Member State.

A second group of important stakeholders is made up of taxpayers, who may want to rely on the DRD for dispute resolution. Experience has shown that only few cases have been dealt with under the EU Arbitration Convention, which was arguably one of the reasons for the adoption of the DRD. The relationship of the DRD to other dispute resolution mechanisms as well as of a potential Standing Committee and the SLAC is not clear at this point. Yet a proposal for a Standing Committee has to be acceptable for taxpayers even if they do not have a choice between the different dispute resolution mechanisms because the taxpayer may otherwise decide not to rely on the DRD, or more specifically the Standing Committee, for dispute resolution at all. This would render the instrument meaningless; the envisaged improvements to tax treaty dispute resolution would not be achieved in practice. Acceptability for the taxpayer involves a variety of aspects, such as the aspects of transparency and predictability mentioned above, the right to intervene and to be heard, the preservation of confidential information, the accessibility and length of the procedure, the quality and correctability of decisions, the independence of the arbitral tribunal, and the enforceability of decisions.

One may also wonder whether the general public and European Union institutions are relevant stakeholders when it comes to acceptability. As to the former, the experience with CETA and TTIP has shown that public support can certainly be of relevance in the establishment of an arbitral tribunal. As to the latter, it is important to note that EU institutions, such as the Commission, are in principle not involved in the establishment of a Standing Committee. Instead, it is for the Member State to design such institution. This means that while a proposal for a Standing Committee has to respect the boundaries laid down by the DRD and other sources of EU law, the Commission plays no active role in the set up and administration of a Standing Committee.

\subsection{Objective 5: Contribution to Future Development of International Tax Law?}

The establishment of a Standing Committee may finally contribute to the development of international tax law. ${ }^{38}$ While the DRD explicitly excludes precedential value of the decisions taken under the directive

\section{Notes}

\footnotetext{
37 See below Proposal 9, 10.

38 See also Govind, supra n. 11, at 322.
} 
in Article 15(4)(1) DRD, any resolution of a tax treaty disputes nonetheless has the potential to serve as a source of inspiration when it comes to deciding similar disputes in the future. This will be all the more so, where the reasoning of the previous decisions is both convincing and easily accessible on some kind of a platform. Indeed, a Standing Committee offers the prospect of more formalized institutional learning and gains from learning by doing. It would also promise formal knowledge management and publication processes, which would prevent the emergence of information asymmetries between those involved in previous cases and any newcomers. At the same time, the sovereignty concerns underlying the rule in Article 15(4)(1) DRD need to be taken seriously: The mere fact that a similar case had been decided in the past is not in itself an argument for taking the same decision in a future case.

\section{Proposal for a standing committee}

\author{
Proposal 1 (Competence): The Standing Committee should \\ have universal competence for all cases of disputes between the \\ participating Member States.
}

The jurisdiction of the Standing Committee has to be delineated from that of the SLAC. There is a choice to be made between universal competence and applicability on a case-by-case basis. The applicability on a case-by-case basis could either consist of an opt-out from a general competence of the Standing Committee or of an opt-in from a general competence of the SLAC. If the latter option were chosen, it would then be necessary to determine who gets to determine the applicable procedure. Universal competence, by contrast, would mean that the participating Member States would automatically submit all cases arising under the directive to the Standing Committee. In this context, we are not concerned with the relationship of the dispute resolution mechanisms on the one hand and other dispute resolution mechanisms on the other hand, such as the EU Arbitration Convention or arbitration under tax treaties, which is spelt out by Article 16(5) DRD. ${ }^{39}$

Such universal competence appears to us as legally feasible, to the extent allowed by Member States' constitutional law: One might perceive a risk of indirectly circumventing the Directive in case Member States were obliged to submit all cases to the Standing Committee. Article 6(1)(b) DRD would become redundant as the
Standing Committee would then have competence over all disputes of that particular Member State. In our view, this risk should not be overestimated: Setting up a Standing Committee is explicitly provided for by the directive. The proposal for a Standing Committee has to stay within these boundaries. In particular, it has to achieve at least a similar level of effectiveness in resolving tax treaty disputes. Where these requirements are met, which would seem to prohibit a 'cosy club of tax officials', the directive is not circumvented. One may also wonder whether Article 10(1)(1) and (1)(2) DRD are based on the premise that the ADRC and the Standing Committee may only be elected on a case-bycase basis. However, the wording of the provisions, which speak of 'may agree to set up' are not clear in this respect. Indeed, the OECD Model Tax Convention contains similar wording entitling the competent authorities to settle questions on the application of certain provisions by mutual agreement. This is generally understood as giving the competent authorities the right to enter into abstract agreements, which apply to all cases rather than to a specific case at hand. ${ }^{40} \mathrm{We}$ believe that Article 10(1)(1) and (1)(2) DRD should therefore equally not exclude abstract mutual agreements. Since there are no explicit rules, which would limit the competence of an ADRC or Standing Committee thus established, we also believe that the Standing Committee can be given universal competence. Against this background, we contend that the Standing Committee should have universal competence. This would ensure a regular flow of cases into the Standing Committee, so as to facilitate the development of experience and know-how. During the initial trial phase, it might be preferable for Member States to limit the competence of the Standing Committee to certain kinds of disputes. However, if the Standing Committee is to have universal competence, it is important that its design lives up to at least the standards of taxpayer protection and effectiveness that are laid down in the DRD for the SLAC.

Proposal 2 (Location): The Standing Committee should be located in a place which is easily reachable for the parties and the arbitral tribunal. From a financing point of view, it would be desirable to rely on existing infrastructures with sufficient capacity for increasing case numbers. The location of the Standing Committee may also be relevant for the review of decisions. Therefore, experience and independence of the judicial system should be kept in mind. Potential locations may be the Hague, Paris or Brussels. We believe a secretariat and administrative staff would be required.

\section{Notes}

39 See Govind \& Turcan, supra n. 9, Ch. 5; S. Piotrowski, Schiedsverfahren in deutschen DBA nach dem MLI, 27 Internationales Steuerrecht 257 (2018); H. M. Pit, Arbitration under the OECD Multilateral Instrument: Reservations, Options and Choices, 71(10) Bull. Int'l Tax'n 568, 585f (2017).

40 See Arts 10(2), 11(2), 27(1)(2) OECD Model Tax Convention (2017). See e.g. R. Ismer, Article 25, in Klaus Vogel on Double Taxation Conventions (E. Reimer \& A. Rust (eds), Wolters Kluwer 2015), m.no. 17. 
The Standing Committee should be permanently located in the same place. While we do think that in the future, it may be possible - and desirable - to conduct the proceedings of the Standing Committee virtually, ${ }^{41}$ we nevertheless contend that in the meantime a physical location appears more realistic. Several places appear possible, which are all easily reachable. Particularly with regard to Brussels, concerns as to the perceived close link to European institutions may arise. Paris, on the other hand, has close perceived links to the OECD Model Tax Convention. When it comes to The Hague, the infrastructure of the Permanent Court of Arbitration could be relied upon. Finally, cities, such as Vienna, Tallinn and Prague, but also, given the rich experience of arbitration in domestic tax matters, Lisbon are conceivable. While these are certainly viable proposals, one also has to keep in mind that tax treaty disputes are distributed very unevenly between Member States and no existing infrastructure that could be relied upon immediately comes to mind. At its chosen location, the Standing Committee would also require a secretariat and administrative staff, which would be in charge of logistics, knowledge management and other matters of administration.

Proposal 3 (Qualification of Members of Standing Committee): Arbitrators should be subject to at least the same requirements as for the SLAC.

Regarding the personal qualification of persons that are eligible for the Standing Committee, we suggest that the same standards be applied as under the MLI. Article 20(2) (a) MLI stipulates that the arbitration panel 'shall consist of three individual members with expertise or experience in international tax matters'. We recommend that the Standing Committee also include transfer pricing experts among its members and have expertise in European Union law, so as to make sure that the solution it proposes does not violate the EU treaties or directives. Having transfer pricing experts seems particularly important if the Standing Committee is to apply the independent opinion approach, as in such a case an economic analysis, potentially including a functional analysis and a benchmarking study, might need to be undertaken as part of the resolution of a case.

Proposal 4 (Composition of Standing Committee for a Specific Case: Independence Requirement): The option for establishing a Standing Committee should not be relied upon so as to circumvent the independence requirements of the DRD. Arbitrators should be subject to at least the same requirements as for the SLAC and should have staggered terms.
Article 10(2) DRD stipulates that the minimum requirements regarding the independence of the members of the ADRC under Article 8(4) and 8(5) DRD must be respected. The exact portent of this referral is unclear. It might be read as excluding any person who - as an independent person of standing - would be ruled out by these provisions. The ADRC could then not have representatives from the tax authorities of the states involved in the dispute. By contrast, the provision may also be understood as imposing independence requirements only for independent persons, i.e. members of the Standing Committee that are not part of the tax authorities involved in the dispute. While the former interpretation would go beyond what is required for the SLAC, it would be in line with the obligations under Article 47 of the Charter of Fundamental Rights. When the arbitral tribunal is made up only of independent persons, a 'right' solution will also become more probable. Even if the directive were not to require such independence, Member States should thus agree on it as a more ambitious approach. Moreover, the danger of arbitrators later accepting employment with the parties in the dispute or to the taxpayers concerned should be addressed through longer cooling-off periods. This is all the more so, when the Standing Committee is also meant to make a contribution to the further development of the international tax regime: then great care should be taken that the process is not tainted by later contractual relationships between the arbitrators and taxpayers involved that call the independence into question.

It should be noted that the composition solely of independent persons has repercussions for the relationship of the Standing Committee to the PAC: Where the complaint is at first rejected by the competent authorities, a PAC may be set up, which decides on the acceptance of the complaint. The composition of the PAC is prescribed by Article 8(1) DRD. Under the DRD, it is only the SLAC, not the PAC that can be replaced by a Standing Committee. One could consider designing the Standing Committee in a way that also complies with the requirements for a PAC. The Standing Committee would then also have to comprise representatives of the Member States according to Article 8(1) DRD. Alternatively, the DRD could be amended, so as to grant Member States a possibility to have the Standing Committee replace both the $\mathrm{PAC}$ and the SLAC, even where the Standing Committee has a different composition.

Given the court-like status of the Standing Committee, we furthermore suggest that at least one of the members the Standing Committee deciding a particular case should be legally qualified. However, we would not go so far as to require an application of Article 8(6) DRD, which

\section{Notes}

41 See C. Dimitropoulou et al., Applying Modern, Disruptive Technologies to Improve the Effectiveness of Tax Treaty Dispute Resolution: Part 2, 46(12) Intertax 960ff (2018). on the use of modern technologies in tax dispute resolution. 
provides that unless otherwise agreed by the independent persons of standing and the competent authorities of the Member States involved in the dispute, the chair shall be a judge. This is not necessary where the arbitral tribunal is wholly made up of independent persons. Moreover, we propose that the members of the Standing Committee have staggered terms, so there is a human continuity in the committee. which would guarantee the practical accessibility of accumulated institutional knowledge.

The independence requirements spelt out above would also prepare the Standing Committee for dealing with multiparty disputes, which may arise under the Directive. Were such disputes dealt with under an approach which does not guarantee the independence of arbitrators, problems of coalition building of some of the parties to the detriment of another party may arise. ${ }^{42}$

Proposal 5 (Procedural Rules and Organization of the Standing Committee): Member States wishing to introduce a Standing Committee will have to agree on a statute, which contains abstract rules on the Standing Committee on the one hand, as well as specific Rules of Functioning for every case. The procedural rules by established players in the field such as the Permanent Court of Arbitration or of Chambers of Commerce could, mutatis mutandis, be taken as a starting point. Certain minimum standards that are only provided for with respect to the SLAC should also be implemented for the Standing Committee. The Standing Committee should be organized in chambers. There should at least be different chambers for transfer pricing disputes on the one hand and other types of tax treaty disputes on the other hand. The bearings of the Standing Committee should be public subject to a veto of the taxpayer and conceivably also the Member States. The Standing Committee should meet on fixed days.

According to Article 10(3) DRD, the competent authorities of the Member States concerned shall agree on the Rules of Functioning. A closer look at Article 11(2) DRD reveals that the Rules of Functioning under this provision contain both elements related to the specific dispute and to the infrastructure and the composition of the arbitral tribunal. As the Standing Committee will be of a permanent nature, it will be necessary to determine some of the elements mentioned in Article 11 DRD in advance. Member States wishing to introduce a Standing Committee will thus have to draft some sort of statute that contains rules on aspects such as competence, infrastructure, abstract logistical arrangements, extent and details of involvement of the taxpayer and third parties (e.g. expert witnesses or competent authorities of third countries in multilateral situations), dispute resolution mechanism, as well as abstract rules on how to set up the arbitral tribunal for specific cases. These abstract rules have to be drafted against the background of practicalities, such as capacity, cost and ease of administration. A second set of Rules of Functioning will have to be agreed upon with regard to the aspects of the specific dispute. The latter contains specifics with respect to the characteristics of the dispute, as well as to the composition of the Standing Committee in the case at hand. Both these sets of rules will have to be communicated to the taxpayer pursuant to Article 11(1)(a) DRD. Depending on how flexible the design of the Standing Committee should be, certain aspects will have to be dealt with in the ad hoc Rules of Functioning instead of the statute or vice versa. Where the Member States wish to provide for leeway for individual cases, they also have to determine who gets to choose what procedure is applicable for a specific case at hand.

As to the design of the procedural rules, Article 10 DRD provides limited guidance: According to Article 10(4) DRD, the rules on the costs of the specific procedure (Article 12 DRD) and information, evidence and hearing (Article 13 DRD) are applicable as default rules unless otherwise agreed by the Member States in the Rules of Functioning. With respect to the costs of the specific procedure (as opposed to the body itself, which would have to be funded by the Member States that set up the Standing Committee), we contend that Member States should not agree on a different set of rules. Instead, they should include Article 12, and in particular the cap of EUR 1,000 per person per day for the remuneration of the arbitrators in the statute of the Standing Committee should apply. ${ }^{43}$ At least initially, there should be no fixed remuneration for the members of the Standing Committee. Article 13(3) DRD on secrecy should also apply. We also contend that the rights of the taxpayer, which are laid down in Article 13(1), (2) DRD, should be strengthened. ${ }^{44}$

Beyond this, the Directive is largely silent on procedural rules for the Standing Committee. We therefore suggest that the procedural rules by established players in the field such as the Permanent Court of Arbitration or of International Chambers of Commerce could be taken as a starting point. ${ }^{45}$ However, when doing this, care should be taken as the procedure under the DRD differs in its nature and objective from international commercial arbitration. Moreover, a few clarifications seem warranted:

\section{Notes}

42 See on this R. Ismer \& S. Piotrowski, A BIT Too Much: Or How Best to Resolve Tax Treaty Disputes?, 44(5) Intertax 348, 356 (2016).

43 However, where procedures are mainly held by way of written procedures, there may be a need for additional compensation beyond the compensation due for every day that the Standing Committee meets pursuant to Art. 12(1)(b) DRD.

44 See infra Proposal 6.

45 See also OECD Model Tax Convention (2017): Commentary to Art. 25(5), the Sample Mutual Agreement on Arbitration provided in the Annex. 
The first clarification concerns timing issues: The DRD provides for specific time frames, which would also be binding for a Standing Committee. However, whereas Article $6 \mathrm{DRD}$ sets time limits for the setting up of the SLAC and the appointment of arbitrators and Article 7 DRD stipulates a remedy under domestic law, a comparable rule cannot be found for the Standing Committee. The taxpayer should be granted a corresponding remedy with regard to the Standing Committee, where the timely set up of the arbitral panel is not already ensured through an automatic appointment system for arbitrators under the statute for the Standing Committee.

Second, the rules on the set up of the Standing Committee are closely linked to organizational aspects, which would also have to be laid down in the statute: First, an allocation of disputes to different chambers would appear desirable due to the distinct challenges posed by transfer pricing disputes on the one hand and other types of tax treaty disputes. Beyond this distinction, it may be possible to identify more types of disputes that should be dealt with by separate chambers. An allocation to chambers depending on the type of dispute would also contribute to the specialization of arbitrators over time. For each chamber, there should then be a separate list of independent persons of standing with tax experts that are qualified to decide this type of dispute.

Third, a choice has to be made on who determines the composition of the arbitral panel for a specific dispute. On the one hand, the composition could be predetermined or the composition could be determined by the secretariat for each individual case. On the other hand, the process could be assimilated to traditional tax treaty arbitration, where - as an emanation of party autonomy - the competent authorities of each Member States each choose one arbitrator who then in turn choose a chair. In our view, the choice of latter approach gives much too weight to the chair, who is the one person where it will generally not be clear ex ante what her decision will be. Moreover, this approach once again cannot easily be extended to multiparty disputes. Therefore, we suggest the first approach. Rules would also have to be put in place on how to replace unsuitable arbitrators for a specific dispute. For instance, we contend that arbitrators should not come from one of the Member States involved in the dispute.

Fourth, we contend that while the hearings of the Standing Committee should generally be public, there may be legitimate concerns with respect to confidential information. Taxpayers may be reluctant to divulge pertinent information if the hearings are public. We therefore propose a right of the taxpayer, and conceivably also of Member States, to request that the hearings be held in private. It would then be for the Committee to decide as to whether and to what extent there are sufficient reasons for excluding public hearings. Beyond this, one may even wonder whether cases may also be submitted to the arbitrators in an anonymized or redacted form, e.g. by means of a standardized application form, so as to ensure neutrality.

Finally, we propose that the Standing Committee should meet on fixed days. For example, arbitrators could be obliged to make long-term reservations for two days per month in their agendas for meetings of the Standing Committee. Where it becomes clear that the services will not be required, the arbitrators could be released from such stand-by duty.

Proposal 6 (Taxpayer rights): The taxpayer rights under the directive should be strengthened. The taxpayer's right to provide evidence and be heard by the Standing Committee should not be subject to the agreement of the competent authorities of the Member States involved in the procedure.

The traditionally weak position of the taxpayer is perhaps the biggest concern for tax treaty arbitration. We believe that the role of the taxpayer in the procedure has to be strengthened beyond what is provided for in the context of dispute resolution by the SLAC. At the same time, it is essential to keep in mind that the Standing Committee is implemented by the Member States. Member States may be reluctant to adopt a proposal which grants the taxpayer the role of a party to the proceedings. Furthermore, such strong position would arguably not be covered by the DRD and would require a new legislative basis approximating the Standing Committee to a court - which is ultimately desirable, but very likely not feasible at this stage. Member States' reluctance to admit the taxpayer as a party to the proceedings is also underlined by the fact that under the directive there is always room for a divergent decision of the competent authorities. As a compromise, we suggest that the involvement of the taxpayer pursuant to Article 13(1), (2) DRD (provision of evidence and right to be heard) should not be subject to the ad hoc agreement of the competent authorities for each individual case. Instead, such rights should be included in the statute of the Standing Committee. ${ }^{46}$ Furthermore, the procedure should not be held behind closed doors. The taxpayer should have a right to be present during the proceedings.

Proposal 7 (Language of the Procedure): The proceedings should generally be held either in the main language of the applicable tax treaty, or, where different, at the choosing of both states, in English.

\section{Notes}

46 Govind, supra n. 11, at 320 notes that the right of the taxpayer to a hearing is not subject to the consent of the competent authorities under the EU Arbitration Convention. In terms of taxpayer protection, the DRD thus appears to be a step back. The situation under Art. 13 DRD appears nonetheless better than that under the MLI, which does not explicitly provide the taxpayer with the possibility to provide information to the arbitration panel. 
We do not consider the approach chosen for proceedings at the CJEU sustainable as it is extremely costly. The Standing Committee should operate relying on as few languages as possible so as to save both cost and time. We propose that the proceedings should generally be held either in the main language of the applicable tax treaty, or, where different, at the choosing of both states, in English. The use of the main language of the treaty is supported by Article 33(1) VCLT. Yet this provision also allows for room for divergence. For example, where transfer pricing disputes are concerned, it might be more appropriate to hold the procedure in English when the transfer pricing documentation is written in English.

Proposal 8 (Decision based on Law, not Equity): The decisions of the Standing Committee must be based on law, not on equity.

Article 14(2) DRD clarifies that the Standing Committee must base its opinion on the provisions of the applicable agreement or convention referred to in Article 1 as well as on any applicable national rules. Whereas the mutual agreement procedure is - at least from a public international law perspective - open to equity considerations, this is no longer the case for the arbitration stage. As a general issue for all arbitration procedures under the dispute resolution directive, agreements under Article 25(3) OECD Model Tax Convention also need to be taken into account if and to the extent such agreements are binding on the respective contracting states.

Proposal 9 (Independent Opinion Approach): We consider the independent opinion approach to be preferable to the baseball approach. If the Standing Committee does apply the baseball approach, it should choose a reasoned baseball approach.

In addition to details on the voting mechanism, which is only partially determined by Article 14(3) DRD, a choice is also to be made between the independent opinion approach, which the SLAC relies on, and alternative dispute resolution mechanisms, in particular the baseball approach. There may be doubts whether the Standing Committee may apply the independent opinion approach based on the wording of Article 10 DRD or whether it can only apply methods other than the independent opinion approach. While the wording of this sentence is indeed ambiguous, Article 11(2)(c) DRD suggests that this is possible. According to this provision, the type of process for any alternative dispute resolution if the process differs from the independent opinion process applied by an Advisory Commission' shall be laid down in the
Rules of Functioning. This appears to suggest that the independent opinion approach may well be relied upon. Article 10(2)(2) DRD should thus be seen as a mere clarification.

If this reading of Article 10 is correct, the question is then which approach the Standing Committee should resort to. We see a risk that Member States set up the Standing Committee as a way out from the independent opinion approach and into the baseball approach. We consider the independent opinion approach to be preferable to the baseball approach: The baseball approach would limit the decision space of the Standing Committee. The - in the eyes of the (independent) Standing Committee - 'right' solution could only become binding, where one of the competent authorities happens to have proposed that solution. In such situation, the constraint that the Standing Committee has to choose the better of the two final offers made by the two competent becomes slack, i.e. ceases to be a restriction. In all other situations, the Standing Committee would be forced to adopt the least bad solution, i.e. a solution is does not consider to be fully correct. While baseball arbitration might have certain pragmatic merits for transfer pricing cases, it is less suitable to more legal issues such as conflicts of qualification, or anti-abuse measures such as the principle purposes test. Such outcome would be at odds with the notion that the arbitration procedure is to yield an outcome based on law, and on law alone. At the same time, affording the Standing Committee the possibility to deviate from the positions of both competent authorities means that each case will be decided on its own merits. Log-rolling, which appears possible under baseball arbitration, is ruled out. Moreover, the application of the independent approach can better contribute to the development of international tax law since it provides an opportunity for fully analysing an issue, instead of choosing the least bad alternative. $^{47}$

Exceptions may, however, be conceivable for transfer pricing cases, where there is not necessarily one 'correct' solution, but rather a range thereof. ${ }^{48}$ Several solutions may be viable within the arm's length range. However, we contend that Article 47 of the Charter of Fundamental Rights requires that if the baseball approach is applied, the arbitral tribunal is nevertheless required to state reasons (reasoned baseball approach). Moreover, even for transfer pricing cases, the taxpayer's interests may go beyond the resolution of the past dispute. An arbitral award with stated reasons would provide him an, albeit not legally binding, indication for the years going forward.

\section{Notes}

47 See Objective 5.

48 Similarly Govind, supra n. 11, at 319. 
Proposal 10 (Legal Reasoning and Publication of Opinions): Opinions by the Standing Committee should provide legal reasons and should as such be published.

Understanding the arbitration stage as a rule-based procedure also suggests that the Standing Committee must state the legal reasons that have led it to adopt its opinion. Whereas Article 14(1) DRD only provides for a delivery of the opinion to the competent authorities, it should also be communicated to the taxpayer, possibly only after the period provided for in Article 15(2)(2) DRD has expired. Moreover, the reasoning should be published. While Article 18 DRD only stipulates that the final decision or (at least) a syllabus be published - which may also be the divergent agreement reached by Member States concerned under Article 15(2) DRD - we believe that the opinion should also be published as such. Taxpayer concerns about confidential information can and should be addressed through appropriate redacting, which is standard practice in domestic tax court procedures. At the least, it should be notified to the taxpayer, which is currently not explicitly provided for by the directive.

Proposal 11 (Review of Decisions): Manifest errors in Final Decisions should be correctable. This would require an amendment of the DRD.

We do not believe that the DRD should provide for a fullfledged second instance. Yet at least manifest errors in decisions should be correctable. Article 15(4) DRD (only) allows for a review of the decision by national courts on grounds of violation of the independence requirements under Article 8 DRD. However, a wider margin for correctability appears desirable, especially if the taxpayer is not a party to the proceedings. Such need arises not so much, when the taxpayer accepts the decision. Where a final decision is contrary to primary EU law, the competent authorities must not apply it. If the Member State falsely assumes a violation of EU law, the taxpayer may bring an action pursuant to Article 15(4) DRD against such non-implementation. A domestic court can then force the Member State concerned to implement the decision. The national court may in the course of this procedure be obliged to refer questions on the interpretation and application of EU law to the CJEU. Where, by contrast the competent authorities implement the decision despite its incompatibility with EU law, the taxpayer will generally have no incentive to bring an action as he has accepted the decision. While the taxpayer can always refuse to accept the final decision pursuant to Article 15 (4) DRD, this implies that the dispute remains unsolved and the taxpayer can only rely on domestic remedies. This issue concerns the decisions not only of the Standing Committee, but also of the SLAC. Yet the decision must also be correctable where the taxpayer does not accept it. This is required for decisions that are incompatible with EU law. Beyond that, it would arguably be necessary to amend the DRD in order to ensure the correctability of other manifest errors. This is due to the institutional architecture of the DRD: As soon as the opinion of the Standing Committee or the SLAC has been officially communicated to the competent authorities, Article 15 is triggered, according to which a review is only possible on grounds of a lack of independence.

\section{Conclusion}

Developing proposals for real-world institutions on green field sites is a task that academia has all too often neglected. As academics, we can and should create ideas for the design of institutions, based on experience from neighbouring fields while recognizing the particularities of taxation in general and tax treaty disputes in particular. Our proposal should be understood as the starting point of a dialogue. It represents an invitation both to academics and to non-academics to contribute their views and expertise. Its broad discussion and ensuing enhancement may persuade Member States to adopt the DRD's proposal for a Standing Committee.

When operational, the Standing Committee could have a major beneficial impact for the development of the international tax regime. This is all the more so as the trend to replacing substantive law with procedures poses dangers to the rule of law and at least requires well-designed procedures. The Standing Committee may also become a role model for dispute settlement under international law more generally. This is not least because the high case numbers of expected disputes, which should outnumber disputes under investment protection treaties, place international tax law among the most relevant fields for dispute resolution under international law. The Standing Committee may therefore serve both as a source of inspiration and as a practical testing ground for institutional features of dispute resolution mechanisms, particularly where they involve not only state actors, but also private economic agents. We therefore hope that a large number of Member States are prepared to take the leap into a new era of resolving tax treaties disputes through the Standing Committee as a new institution. 